\title{
Perancangan Aplikasi Surat Menggunakan Framework Codeigniter Dan Bootstrap Pada LPPM Universitas Mohammad Husni Thamrin
}

\author{
Abu Sopian")1), Rano Agustino ${ }^{2)}$, Agus Wiyatno ${ }^{3)}$ \\ ${ }^{1)}$ Program Studi Teknik Informatika, Universitas Mohammad Husni Thamrin \\ ${ }^{2}$ Program Studi Sistem Informasi, Universitas Mohammad Husni Thamrin \\ ${ }^{3)}$ Program Studi Sistem Informasi, STMIK Nusa Mandiri \\ ${ }^{*}$ Correspondence Author: ianprosia2@gmail.com, Jakarta, Indonesia \\ DOI: https://doi.org/10.37012/jtik.v6i2.297
}

\begin{abstract}
Abstrak
Saat ini merupakan Era Revolusi Industri 4.0, dimana sektor industri serta perusahaan dan organisasi di berbagai bidang dituntut untuk berubah. Perubahan ini terjadi ketika teknologi informasi dan komunikasi digunakan untuk mencapai titik tertinggi dalam penggunaan teknologi digital. Era Industri 4.0 telah memberikan dampak yang sangat pesat pada semua aktivitas yang dilakukan di sektor industri dan organisasi organisasi perusahaan. Semakin tinggi teknologi informasi dan komunikasi yang digunakan maka proses penyampaian informasi akan semakin cepat. Proses informasi yang cepat dapat membantu kelancaran kegiatan administrasi di suatu perusahaan atau organisasi, terutama kegiatan administrasi yang berkaitan dengan kegiatan korespondensi. Dalam pengelolaan surat masuk dan keluar pada Lembaga Penelitian dan Pengabdian kepada Masyarakat (LPPM) Universitas Mohammad Husni Thamrin, saat ini terdapat kekurangan-kekurangan yang masih disimpan dan dicatat dalam pembuatan korespondensi. Hal ini dapat mengakibatkan informasi yang disajikan terlambat. Untuk itu perlu adanya suatu teknologi yang akan membantu kelancaran administrasi dalam melakukan korespondensi dengan menulis surat di Lembaga Penelitian dan Pengabdian kepada Masyarakat (LPPM) Universitas Mohammad Husni Thamrin. Pembuatan aplikasi surat dilakukan dengan cepat dan mudah dengan menggunakan UML (Unfied Modeling Language) sebagai alat bantu yang membantu menganalisa alur sistem korespondensi dan memudahkan dalam membangun aplikasi yang dibutuhkan serta dalam proses pembangunan. Dengan bantuan MySQL sebagai database, Bootstrap Framework dan menggunakan bahasa pemrograman PHP.
\end{abstract}

Kata kunci: Desain, Surat, UML, Codeigniter, Bootstrap

Currently it is the Era of the Industrial Revolution 4.0, where the industrial sector as well as companies and organizations in various fields are required to change. This change is when information and communication technology is used to reach the highest point in the use of digital technology. The Industrial Era 4.0 has had a rapid impact on all activities carried out in the industrial sector and company organizational organizations. The higher the information and communication technology used, the faster the information delivery process will be. A fast information process can help the smooth running of administrative activities in a company or organization, especially administrative activities related to correspondence activities. In managing incoming and outgoing letters at the Institute for Research and Community Service (LPPM) at Mohammad Husni Thamrin University, currently there are shortcomings that are still stored and recorded in making correspondence. This can result in information being presented too late. It is that the need for a technology that will help of the smooth running of the administration in making correspondence by writing letters at the Institute for Research and Community Service (LPPM) at Mohammad Husni Thamrin University. Making a letter application is done quickly and easily by using UML (Unfied Modeling Language) as a tool that helps analyze the flow of the correspondence system and makes it easier to build applications that are needed as well as in the development process. With the help of MySQL as a database, Bootstrap Framework and using the PHP programming language.

Keywords: Design, Letter, UML, Codeigniter, Bootstrap 


\section{PENDAHULUAN}

Saat ini merupakan Era Revolusi Industri 4.0, dimana sektor industri maupun perusahaan dan organisasi diberbagai bidang dituntut untuk berubah. Perubahan itu adalah dimana teknologi informasi dan komunikasi dimanfaatkan sepenuhnya guna mencapai efisiensi yang setinggi-tingginya dengan penggunaan pemanfaatan teknologi digital. Era Industri 4.0 membawa pengaruh yang pesat terhadap seluruh kegiatan yang dilakukan dalam sektor industri dan perusahaan maupun organisasi. Semakin tinggi teknologi informasi dan komunikasi yang digunakan akan semakin mempercepat proses penyampaian informasi. Proses informasi yang cepat dapat membantu kelancaran kegiatan administrasi pada perusahaan maupun organisasi, khususnya kegiatan administrasi yang berkaitan dengan aktivitas surat menyurat.

Universitas Mohammad Husni Thamrin adalah sebuah perguruan tinggi yang memiliki beberapa lembaga, diantaranya Lembaga Penelitian dan Pengabdian Masyarakat (LPPM) yang berfungsi untuk mengelola semua kegiatan penelitian dan pengabdian kepada masyarakat. Kegiatan penelitian itu dilakukan oleh dosen untuk peningkatan kualitas dosen tersebut. Dalam pengelolaan surat masuk dan surat keluar pada Lembaga Penelitian dan Pengabdian Masyarakat (LPPM) di Universitas Mohammad Husni Thamrin saat ini masih memiliki kekurangan diantaranya, pembuatan surat menyurat masih dicatat dan dibukukan secara manual. Hal ini mengakibatkan informasi yang disajikan terlambat. Untuk itu perlunya suatu teknologi yang dapat membantu efektivitas kelancaran administrasi dalam pembuatan surat menyurat dengan pembuatan aplikasi surat pada Lembaga Penelitian dan Pengabdian Masyarakat (LPPM) di Universitas Mohammad Husni Thamrin. Sistem ini dapat mendukung terciptanya informasi dan komunikasi yang efisien.

Pembuatan aplikasi surat dilakukan secara cepat dan mudah dengan menggunakan $U M L$ (Unfied Modeling Language) sebagai alat yang membantu analisa alur sistem surat menyurat. UML memudahkan dalam pembangunan aplikasi yang dibutuhkan juga dalam proses pengembangannya. Dengan dibantu MySQL sebagai database, Framework Bootstrap dan menggunakan bahasa pemrograman PHP.

Adapun yang menjadi landasan teori yang digunakan dalam melakukan perancangan aplikasi surat pada Lembaga Penelitian dan Pengabdian Masyarakat (LPPM) Universitas Mohammad Husni Thamrin adalah sebagai berikut:

Perancangan aplikasi surat masuk dan keluar pada PT. Angkasa Pura 1 Semarang oleh Endang Sugiharti dan Sulis Eli Triliani tahun 2014. Aplikasi dirancang menggunakan Visual Basic. Hasil yang diperoleh yaitu proses penginputan, pencarian data surat masuk / 
surat keluar dan pembuatan laporan dapat dilakukan kapan saja dalam waktu yang cepat karena data tersimpan dengan aman dan terstruktur serta tidak terjadi lagi keterlambatan dalam pencarian data. Dengan adanya aplikasi data surat masuk dan surat keluar yang berbasiskan komputerisasi dapat meningkatkan produktifitas kerja khususnya dari segi proses pengelolaan surat masuk / keluar dan pembuatan laporan akan menjadi cepat dan akurat (Sugiharti \& Triliani, 2014).

Perancangan aplikasi sistem persuratan berbasis web pada PT. Dwi Pilar Pratama oleh Dewi Leyla Rahmah tahun 2014. Aplikasi dirancang menggunakan bahasa pemrogramam PHP dengan menggunakan metode grounded research. Pada aplikasi ini, administrator dapat menangani pekerjaan persuratan dengan cepat dan akurat serta dapat di up-date dengan mudah. Dengan adanya aplikasi ini mempermudah kegiatan atau aktivitas pekerjaan administrator dan pegawai PT. Dwi Pilar Pratama yang memerlukan kecepatan dan ketetapan informasi (Rahmah, 2014).

Rancang bangun aplikasi surat masuk dan surat keluar berbasis web pada kantor asuransi jiwa kantor layanan administrasi Bandung oleh Irwin Supriadi, Rinda Andrayani dan Vera Trysda Maulydda tahun 2018. Aplikasi dirancang menggunakan metode prototype. Aplikasi surat masuk dan surat keluar dapat menyimpan berkas surat secara aman serta berkas surat yang disimpan dapat dilihat dan dicari sesuai dengan kebutuhan (Supriadi, Indrayani, \& Maulydda, 2018).

Menurut George M.Scott Perancangan adalah suatu jaringan kerja yang saling berhubungan untuk menentukan bagaimana suatu sistem menyelesaikan apa yang mesti diselesaikan (Jogiyanto, 1991).

Definisi yang lain mengatakan perancangan adalah proses penerapan berbagai teknik dan prinsip dengan tujuan untuk mentransformasikan hasil analisa kedalam bentuk yang memudahkan pengimplementasian (Abdul Kadir, 2003). Dari pengertian-pengertian di atas dapat disimpulkan perancangan adalah suatu kegiatan yang berhubungan berdasarkan evaluasi yang telah dilakukan pada kegiatan analisis.

Surat adalah sarana komunikasi untuk menyampaikan informasi tertulis oleh suatu pihak kepada pihak lain. Fungsinya mencakup lima hal: sarana pemberitahuan, permintaan, buah pikiran, dan gagasan; alat bukti tertulis; alat pengingat; bukti historis; dan pedoman kerja (Wursanto, 1991).

Surat masuk adalah semua jenis surat yang diterima dari instansi lain maupun dari perorangan, baik yang diterima melalui pos (kantor pos) maupun yang diterima dari kurir (pengiriman surat) dengan mempergunakan buku pengiriman (Wursanto, 1991).Surat keluar ialah surat yang lengkap (bertanggal, bernomor, berstempel dan telah ditandatangani 
oleh pejabat yang berwenang) yang dibuat oleh suatu instansi atau lembaga lain.

UML adalah alat bantu analis serta perancangan perangkat lunak berbasis objek (Nugroho, 2015). UML membantu pendeskripsian dan desain system perangkat lunak, khususnya sistem yang dibangun menggunakan pemrograman berorientasi objek (Fowler, 2005). UML saat ini sangat banyak dipergunakan dalam dunia industri yang merupakan standar bahasa pemodalan umum dalam industri perangkat lunak dan pengembangan sistem. Diantaranya use case diagram, activity diagram dan class diagram.

Bootstrap adalah sebuah library framework CSS yang dibuat khusus untuk bagian pengembangan front-end website (Zakir, 2016). Bootstrap juga merupakan salah satu framework HTML, CSS dan javascript yang paling populer di kalangan web developer yang digunakan untuk mengembangkan sebuah website yang responsive. Sehingga halaman website nantinya dapat menyesuaikan sesuai dengan ukuran monitor device (desktop, tablet, ponsel) yang digunakan pengguna disaat mengakses website website dari browser.

Codeigniter merupakan sebuah framework PHP yang berupa kumpulan folder dan file PHP, JavaScript, CSS, TXT, dan file berbasis web lainnya (Sofwan, 2016). Di dalam Framework Codeigniter terdapat kelas yang berbentuk library dan helper berfungsi untuk membantu programmer dalam mengembangkan aplikasi. Konsep dalam Framework Codeigniter yaitu dengan menerapkan konsep Model, View, dan Controller (MVC). MVC adalah sebuah pola perancangan atau arsitektur yang digunakan untuk rekayasa perangkat lunak dimana para pengembang dapat memisahkan kode program kedalam tiga kelompok yaitu Model, View dan Controller (Sidik, 2012).

\section{METODE}

Model-View-Controller atau MVC adalah sebuah metode untuk membuat sebuah aplikasi dengan memisahkan data (Model) dari tampilan (View) dan cara bagaimana memprosesnya (Controller). Dalam implementasinya kebanyakan framework dalam aplikasi berbasis arsitektur MVC memisahkan pengembangan aplikasi berdasarkan komponen utama yang membangun sebuah aplikasi seperti manipulasi data, antarmuka pengguna, dan bagian yang menjadi kontrol dalam sebuah aplikasi.

Dalam MVC model menggambarkan informasi (data) dan proses bisnis. Tampilan (View) berisi elemen antarmuka seperti text, gambar, ataupun form masukan, sementara controller mengatur komunikasi antara view dan model. Jika dipetakan alur kerja sebuah MVC akan tampak seperti Gambar 1. 


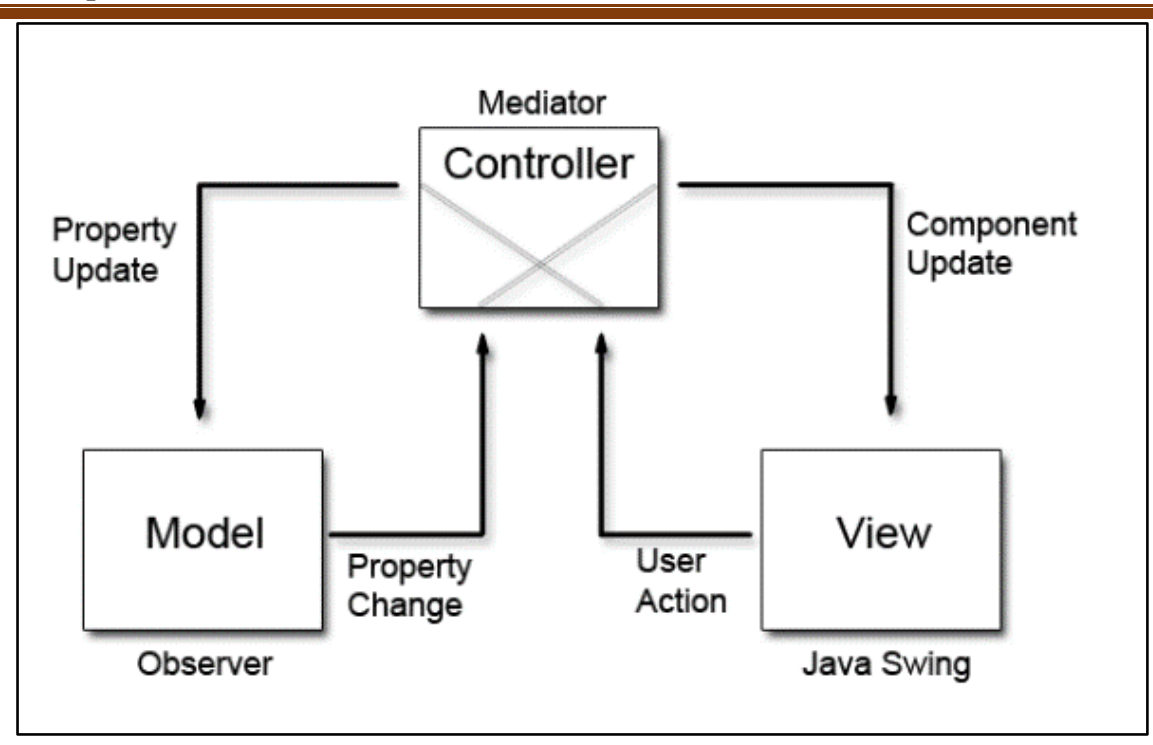

Gambar 1. Model View Controller (MVC)

Tahap penelitian dalam perancangan aplikasi surat yaitu menggunakan metode pengembangan software SDLC dengan model waterfall seperti pada gambar 2.

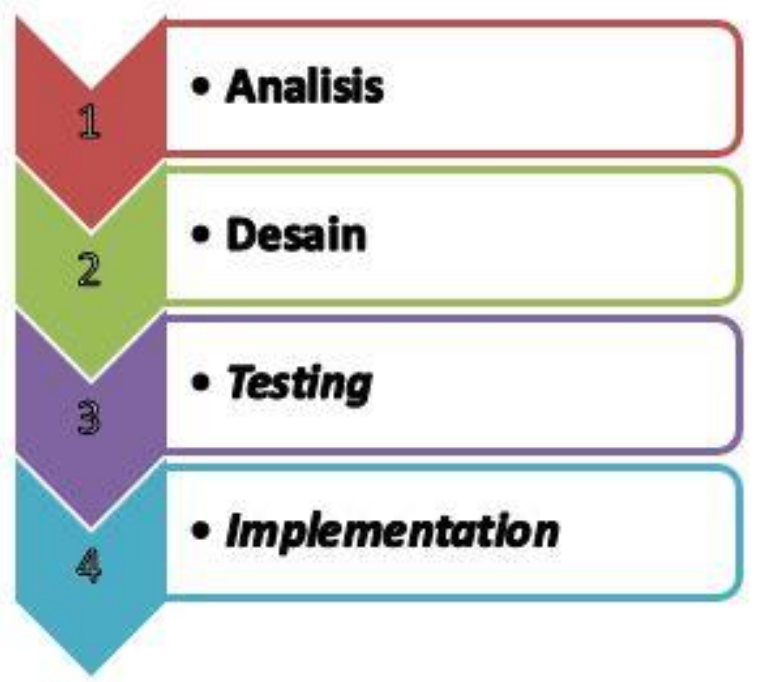

Gambar 2. Desain Penelitian Metode SDLC Waterfall

Berikut tahapan yang dilakukan :

\section{Analisis}

Pada tahapan ini dilakukan analisa kebutuhan dan teknik pengumpulan data dan pembuatan usecase diagram, activity diagram.

\section{Desain}

Pada tahapan ini dilakukan pembuatan class diagram, pemodelan data dan pembuatan kode program serta perancangan database. 


\section{Testing}

Pada tahapan ini dilakukan pengujian (Testing) pada aplikasi surat dengan menggunakan pendekatan black box testing yaitu menguji perangkat lunak dari segi spesifikasi fungsional tanpa menguji desain dan kode program. Pengujian yang dilakukan oleh perancang aplikasi untuk mendapatkan set kondisi masukkan yang sepenuhnya akan melaksanakan semua persyaratan fungsional suatu program atau pengujian tanpa melihat alur eksekusi program, namun cukup dengan memperhatikan apakah setiap fungsi sudah berjalan dengan baik.

\section{Implementation}

Pada tahapan ini adalah tahapan terakhir dimana dilakukan documentation dan delivery. Documentation yaitu tahapan untuk pendokumentasian seluruh aspek tahapan perancangan aplikasi. Sedangkan delivery yaitu tahapan dimana aplikasi dilakukan penyerahan kepada customer.

Dari analisis sistem berjalan terdapat beberapa user, diantaranya admin dan dosen. Transaksi yang dilakukan oleh admin, yaitu :

1. Login untuk mengakses aplikasi surat.

2. Membuat pengajuan surat.

3. Melihat pengajuan surat.

4. Memproses surat.

5. Mengupload surat tugas yang telah ditandatangani oleh LPPM.

6. Melihat list surat pengajuan yang selesai proses.

7. Melihat list surat yang ditolak

8. Melihat dan menambah master user.

9. Melihat dan menambah master jenis pengajuan surat.

10. Dapat mengubah password.

Sedangkan transaksi yang dilakukan oleh dosen, yaitu :

1. Login untuk mengakses aplikasi surat.

2. Membuat pengajuan surat.

3. Melihat pengajuan surat.

4. Melihat pengajuan surat yang telah diproses admin.

5. Melihat dan dapat mengunduh surat yang telah selesai diproses atau ditandatangani oleh LPPM.

6. Melihat pengajuan surat yang ditolak.

7. Dapat mengubah password. 


\section{HASIL DAN PEMBAHASAN}

Pembuatan Use Case yang dibuat setelah melakukan analisa terhadap analisis sistem berjalan dapat dilihat pada gambar 3 dibawah ini :

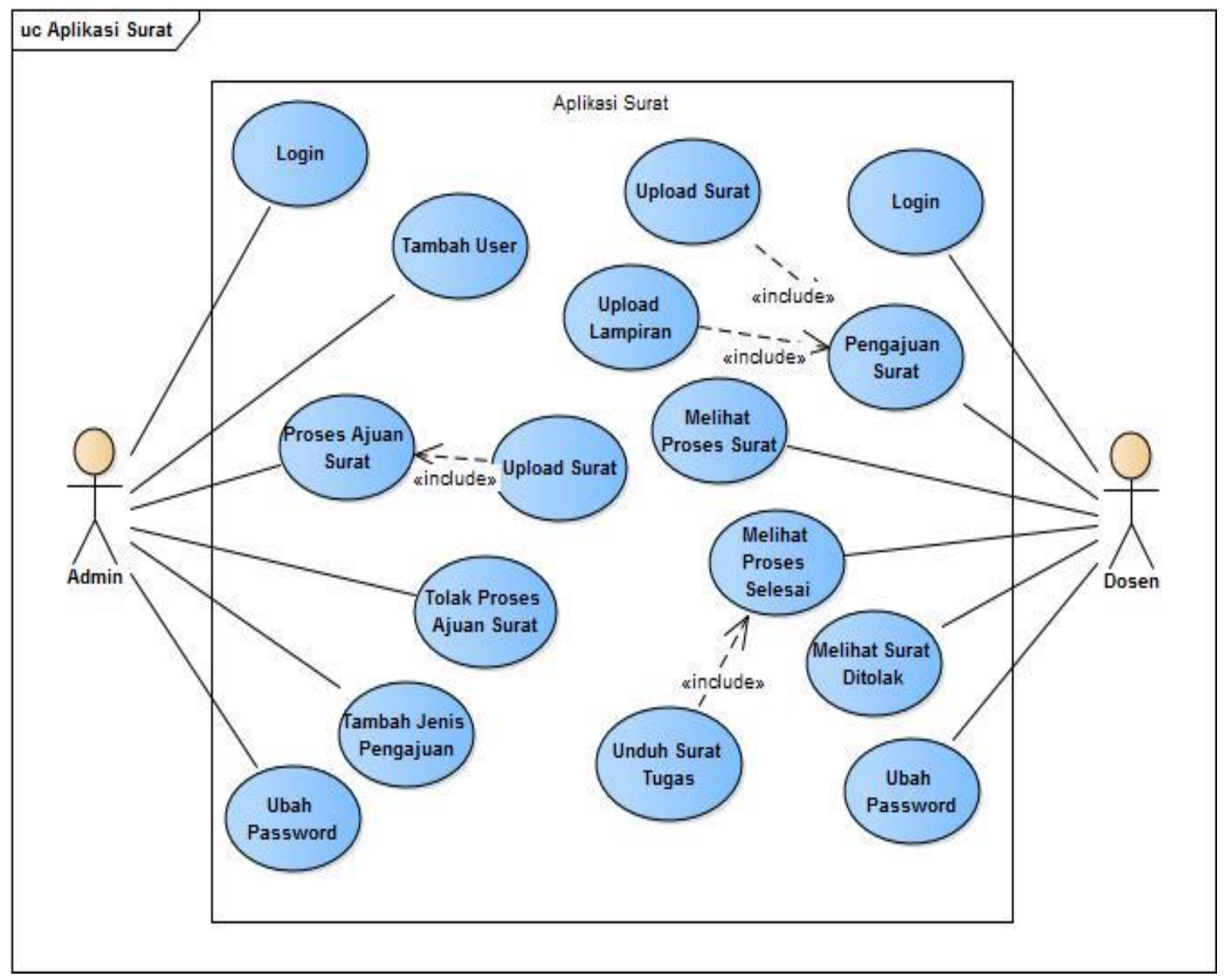

Gambar 3. Diagram Use Case Aplikasi Surat

Penjelasan pada gambar 3 tersebut adalah sebagai berikut : Terdapat 2 aktor utama yaitu dosen dan admin. Dosen dapat login aplikasi, dapat melakukan pengajuan surat termasuk upload berkas file surat pengajuan dan lampiran, melihat proses surat, melihat proses surat selesai termasuk dapat mengunduh surat yang telah telah ditandatangani oleh LPPM, melihat proses surat ditolak, dan dapat mengubah password. Admin dapat login aplikasi, menambah user, menambah jenis pengajuan, memproses ajuan surat termasuk upload surat yang telah ditandatangani oleh LPPM, dapat menolak ajuan surat, dan dapat mengubah password.

Activity diagram dibuat berdasarkan aktivitas yang terjadi dalam sistem berjalan. Diagram aktivitas dapat dilihat pada gambar dibawah berikut ini: 


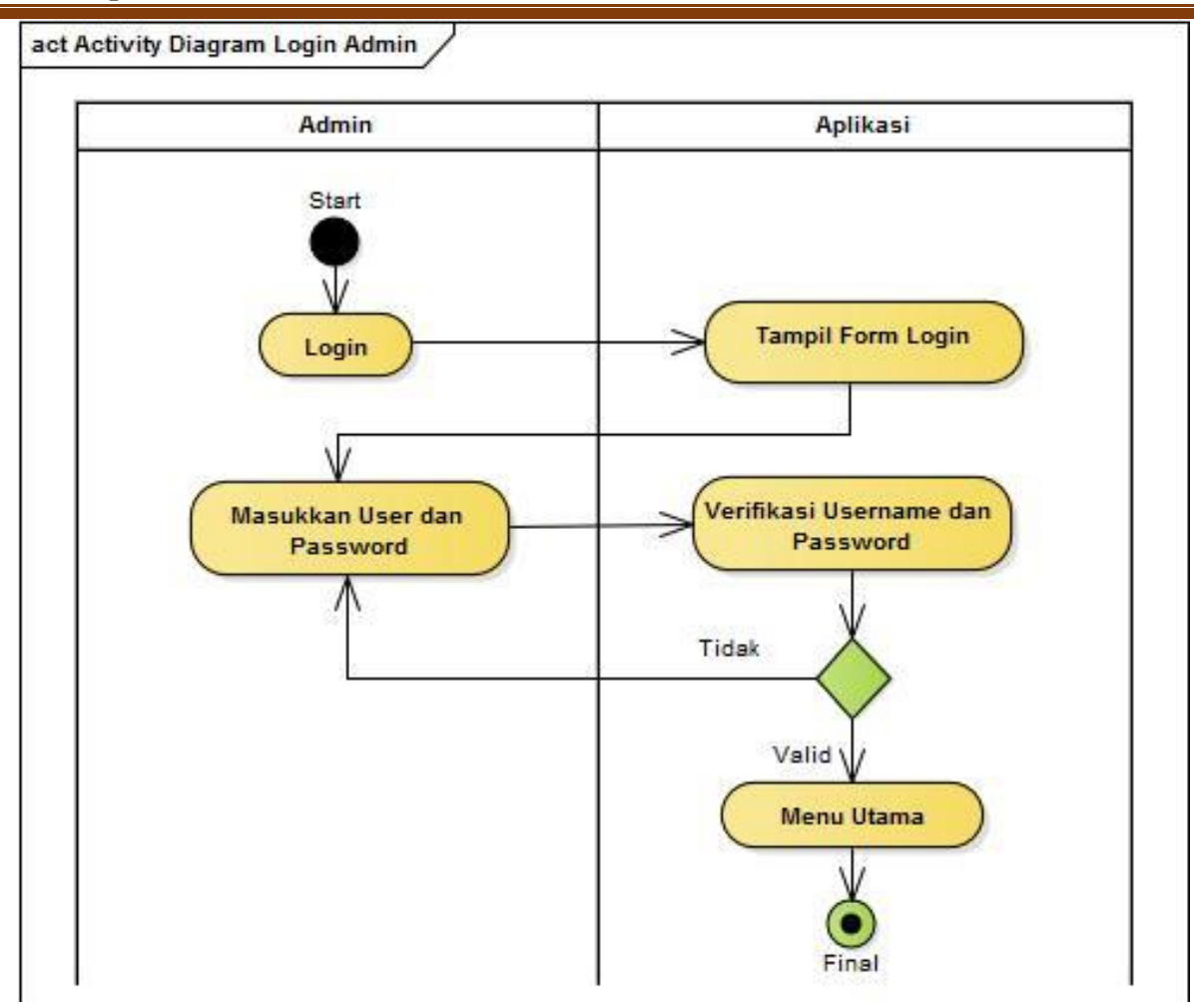

Gambar 4. Activity Diagram Login Admin

Penjelasan untuk gambar 4 adalah diagram aktivitas admin melakukan proses login pada aplikasi surat.

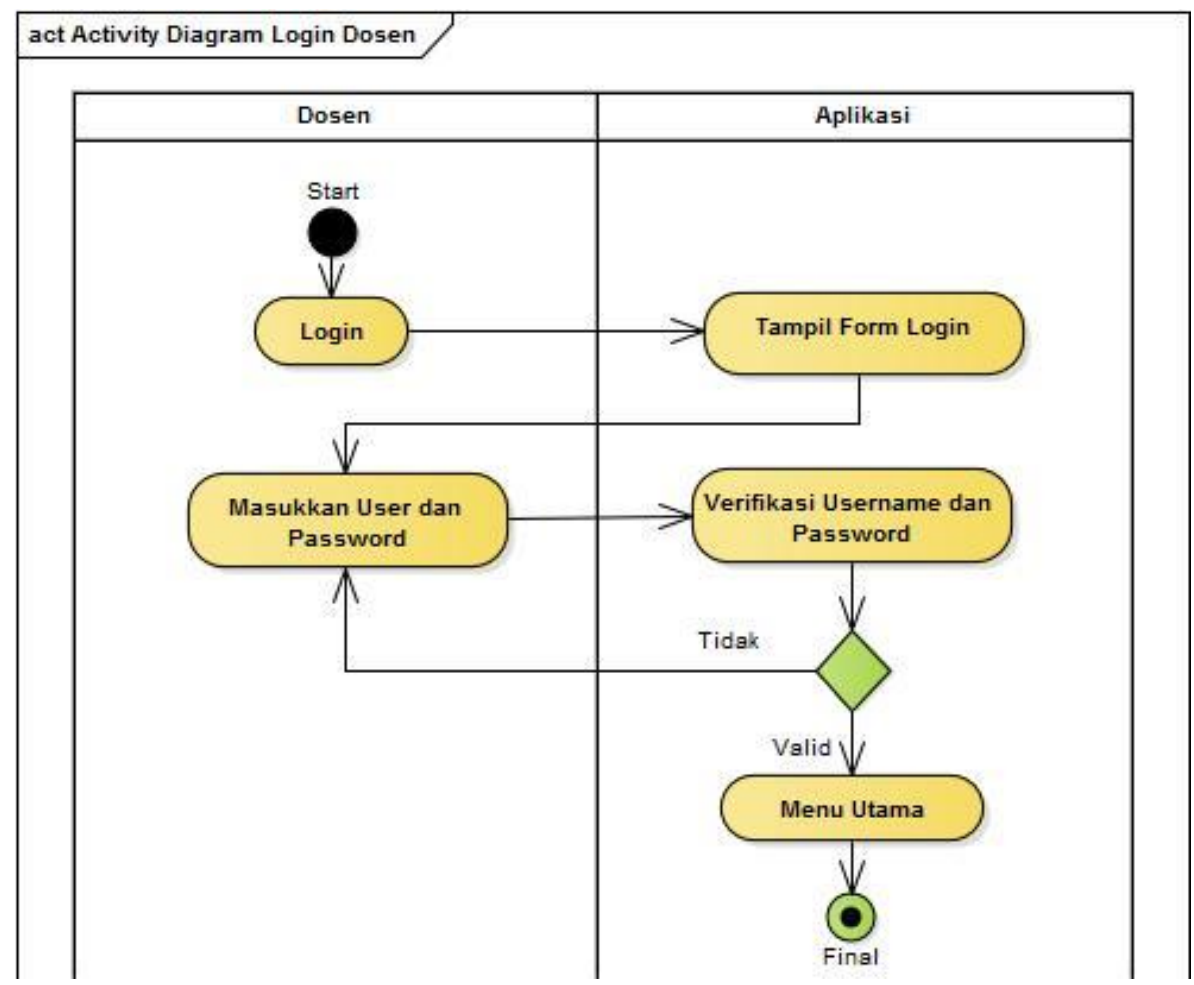

Gambar 5. Activity Diagram Login Dosen

Penjelasan untuk gambar 5 adalah diagram aktivitas dosen melakukan proses login pada aplikasi surat. 


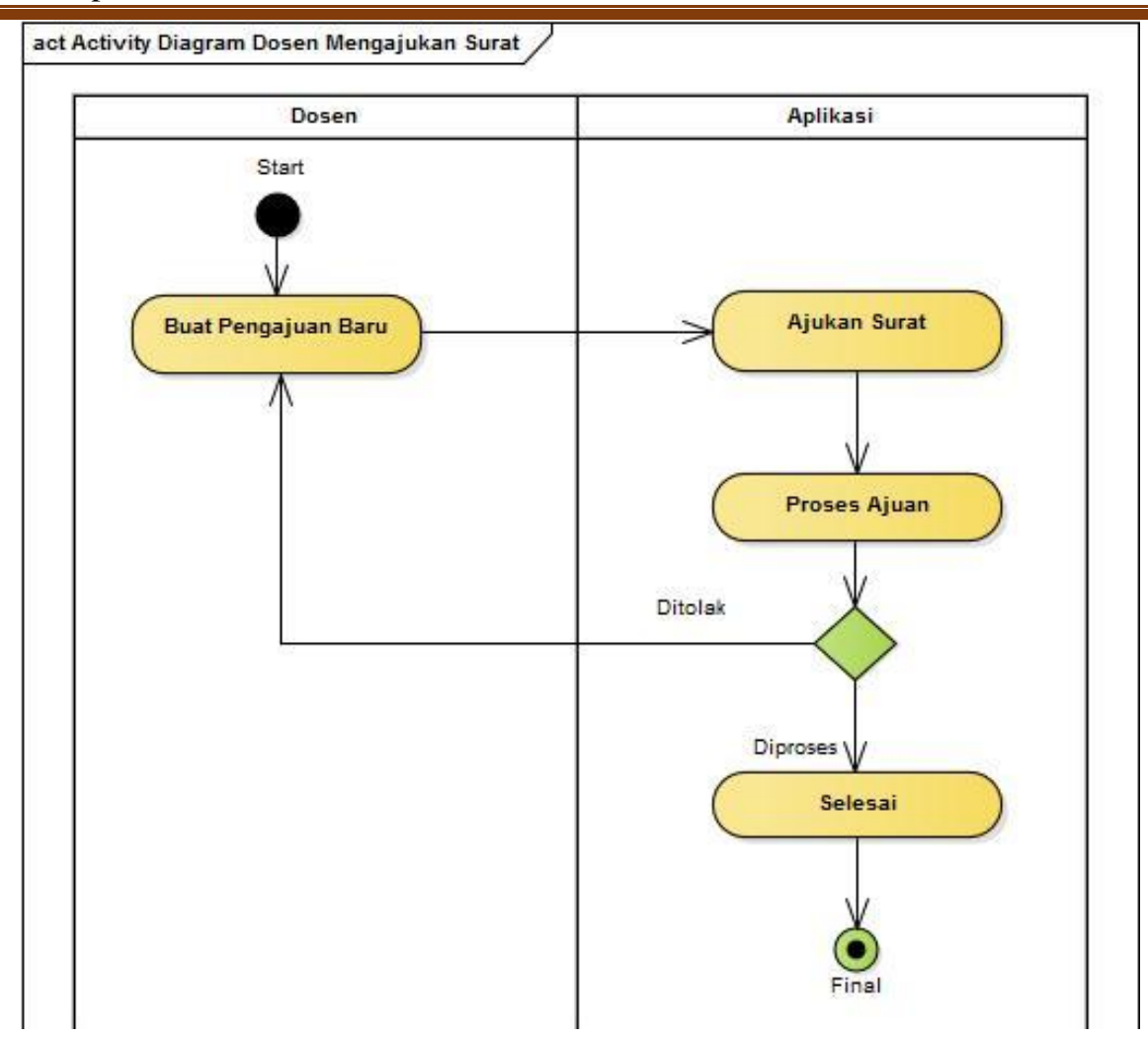

Gambar 6. Activity Diagram Dosen Mengajukan Surat

Penjelasan untuk gambar 6 adalah diagram aktivitas dosen melakukan pengajuan surat pada aplikasi surat.

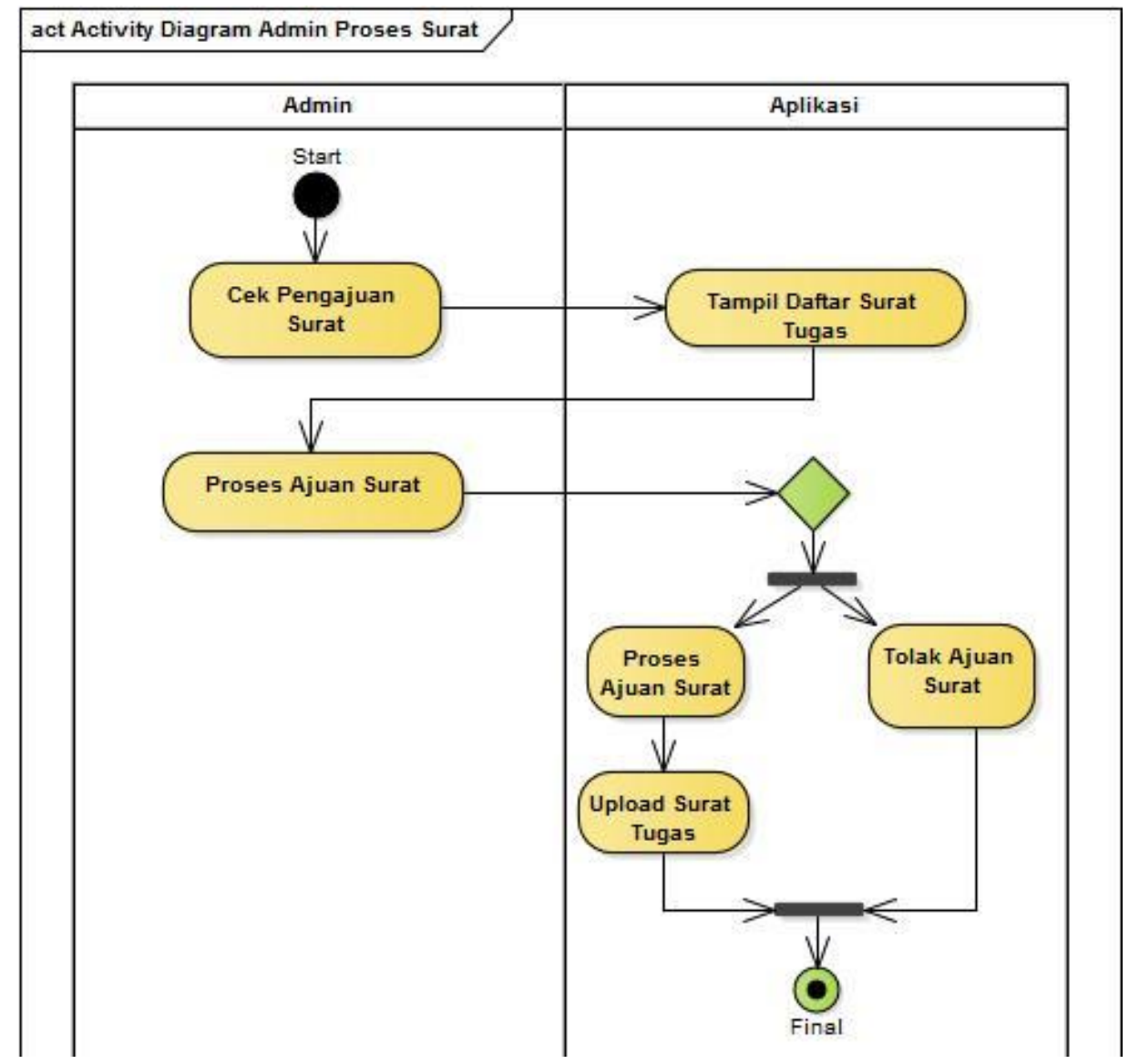

Gambar 7. Activity Proses Surat Admin 
Penjelasan untuk gambar 7 adalah diagram aktivitas admin memproses ajuan surat dari dosen pada aplikasi surat.

Database yang digunakan dalam perancangan aplikasi surat ini adalah dengan menggunakan MySQL. Dengan hasil desain sebagai berikut :

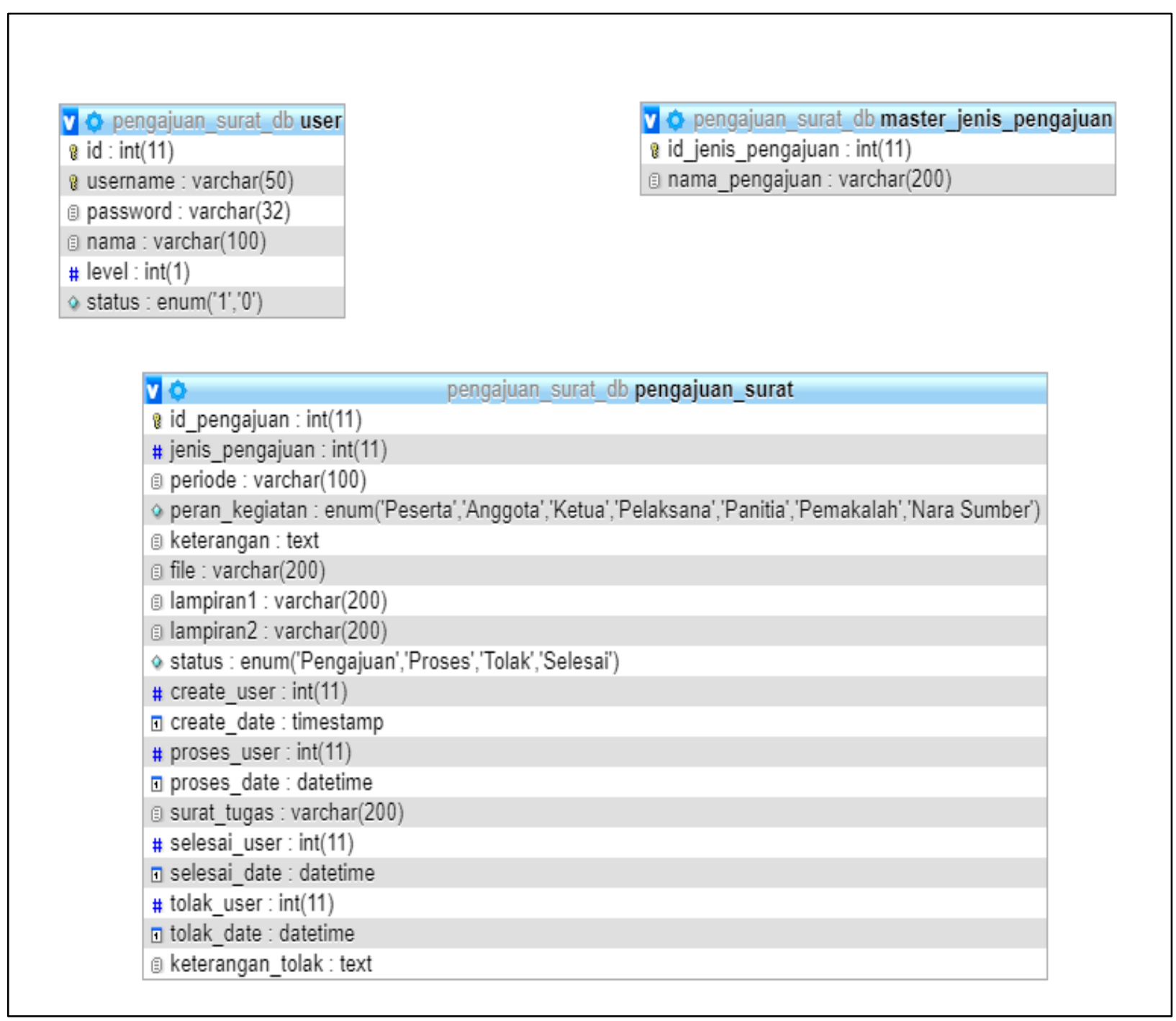

Gambar 8. Perancangan Database

Penjelasan untuk gambar 8 perancangan database diatas adalah: master pengajuan surat, master jenis pengajuan surat dan master user.

Perancangan aplikasi adalah rancangan keluaran yang merupakan rancangan desain tampilan dari aplikasi surat yang informasinya berasal dari pembuat, kemudian informasi tersebut disusun dan ditampilkan kepada pengguna. Dalam merancang tampilan, rancangan harus mudah digunakan oleh pengguna agar pengguna dapat dengan mudah menggunakan fitur yang ada pada aplikasi surat tersebut. Kemudahan akan mempengaruhi efektivitas dan efisiensi pengguna dalam menjalankan pekerjaanya.

Perancangan aplikasi dengan framework Codeigniter dimulai dari pembuatan base URL di config.php yang terletak pada folder Codeigniter. Base URL adalah link tetap untuk 
mengakses resources dan link lainnya. Setelah pembuatan base URL dilanjutkan dengan menghubungkan codeigniter dengan bootstrap. Bootstrap diletakkan didalam folder assets. Folder assets dibuat untuk menampung file atau folder dari luar folder codeigniter.

Model View Controller (MVC) pada perancangan aplikasi surat ini adalah sebagai pola arsitektur. Dimana aplikasi dibagi tiga folder utama yaitu folder Model, folder view dan folder controller. Request (permintaan) browser ditangani oleh bagian Controller. Controller akan melakukan pemanggilan ke Model untuk mendapatkan data yang relevan, dan kemudian mempersiapkan data tersebut untuk ditampilkan (View). Controller memberikan data yang diperlukan kepada view. View menampilkan data dan berbagai elemen antarmuka tambahan yang diperlukan.

Aplikasi surat ini memiliki dua level user yaitu administrator dan admin dengan masingmasing user tersebut diatas memiliki hak akses yang berbeda. Untuk masuk kedalam aplikasi surat, user perlu melakukan login dengan cara memasukkan username dan password. Halaman login user dapat dilihat pada gambar 9 sebagai berikut:

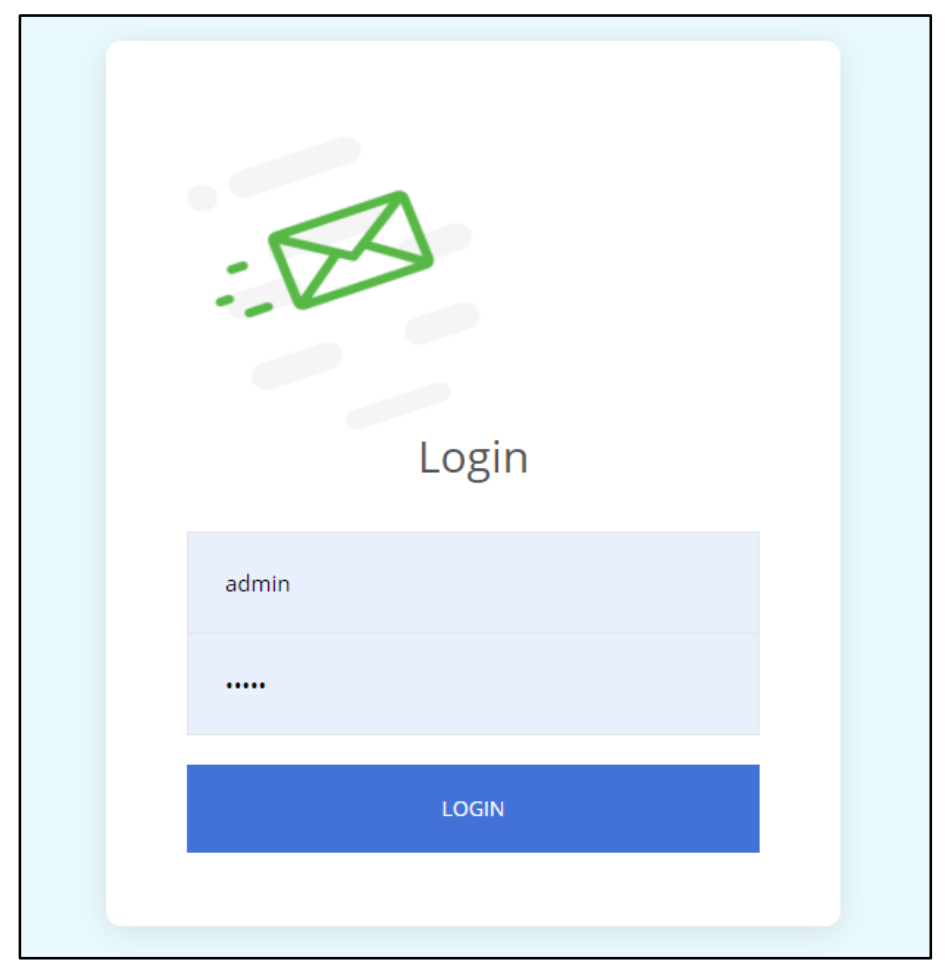

Gambar 9. Halaman Login

Setelah user sukses dalam proses login dengan cara mengisikan username dan password, maka akan tampil halaman utama dari aplikasi surat. Gambar 10 adalah tampilan halaman utama aplikasi surat. 


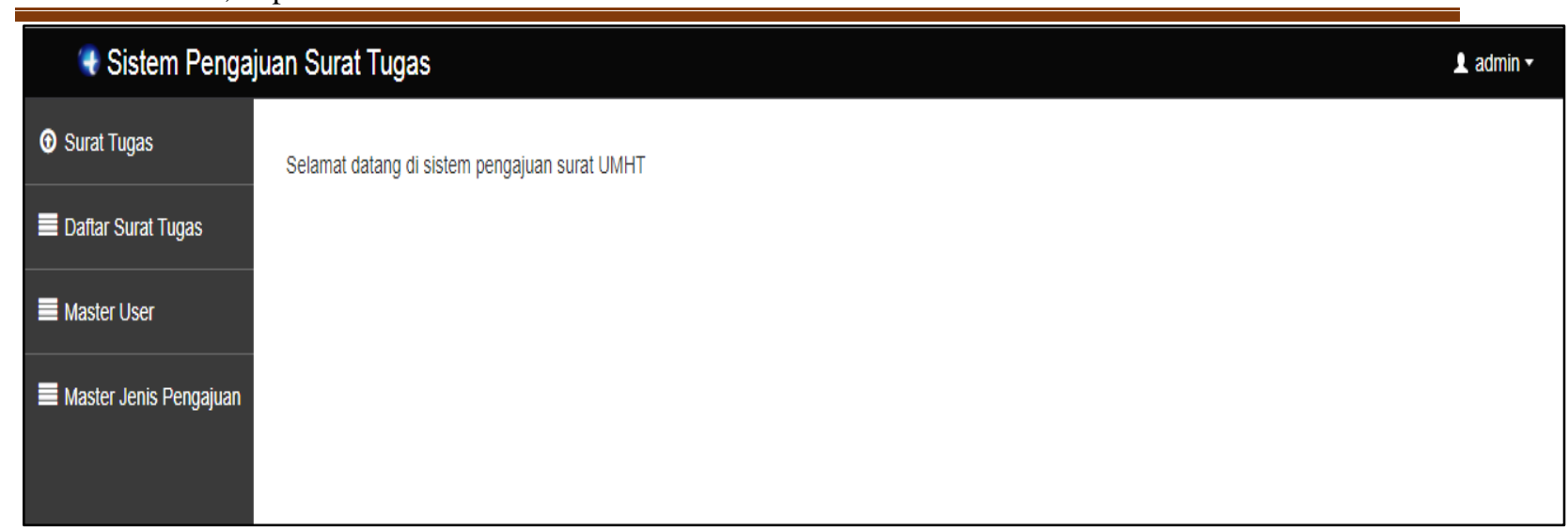

Gambar 10. Menu Utama Admin

Pada menu utama admin terdiri dari menu surat tugas yang digunakan untuk pengajuan surat, menu daftar surat tugas yaitu menu untuk melihat ajuan surat dosen dan memproses ajuan surat dosen, menu master user yaitu menu untuk melihat dan menambahkan user serta menu master jenis pengajuan yaitu menu untuk melihat dan menambah jenis pengajuan, dan menu untuk mengubah password.

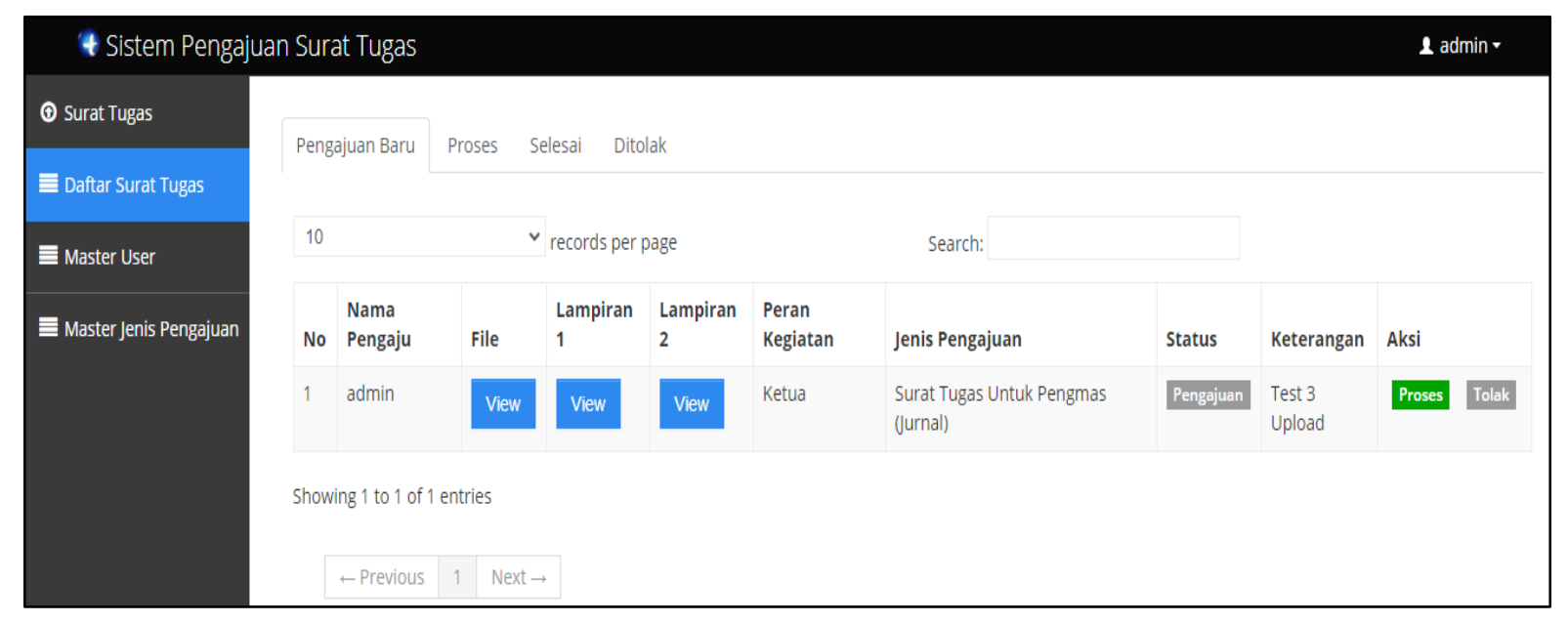

Gambar 11. Menu Melihat Ajuan Surat

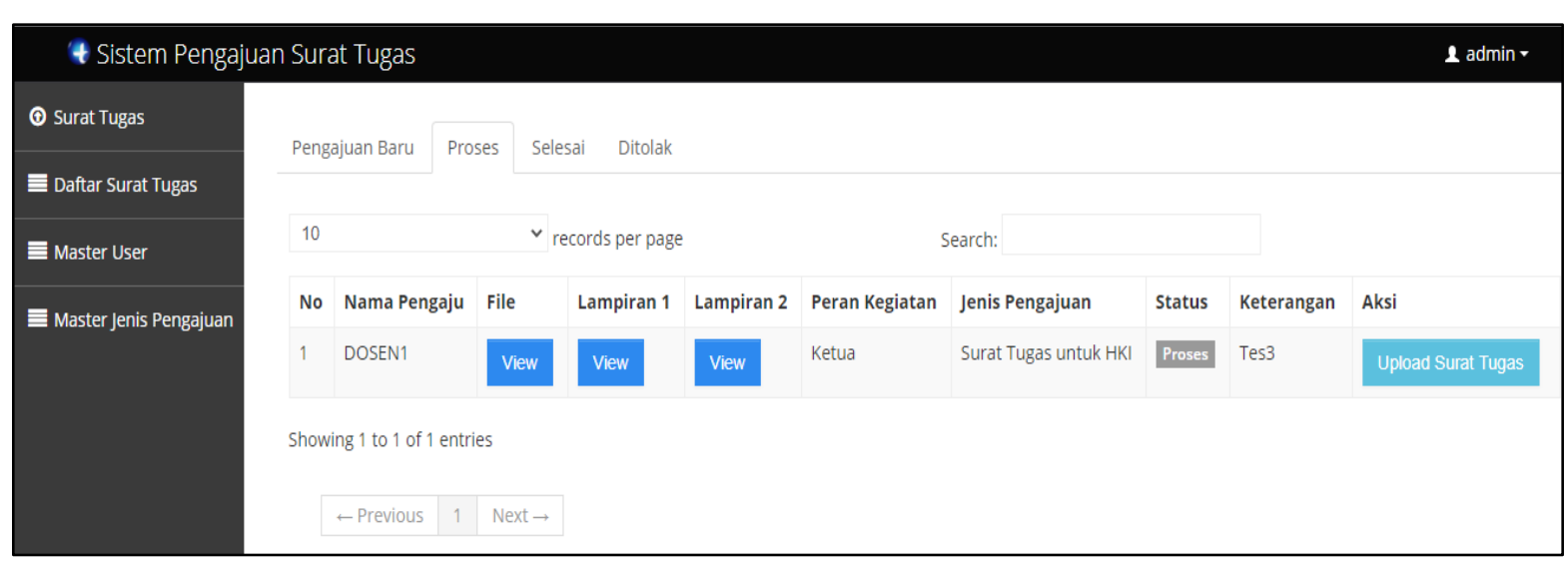

Gambar 12. Menu Proses Ajuan Surat 
Volume 6 No 2; September 2020

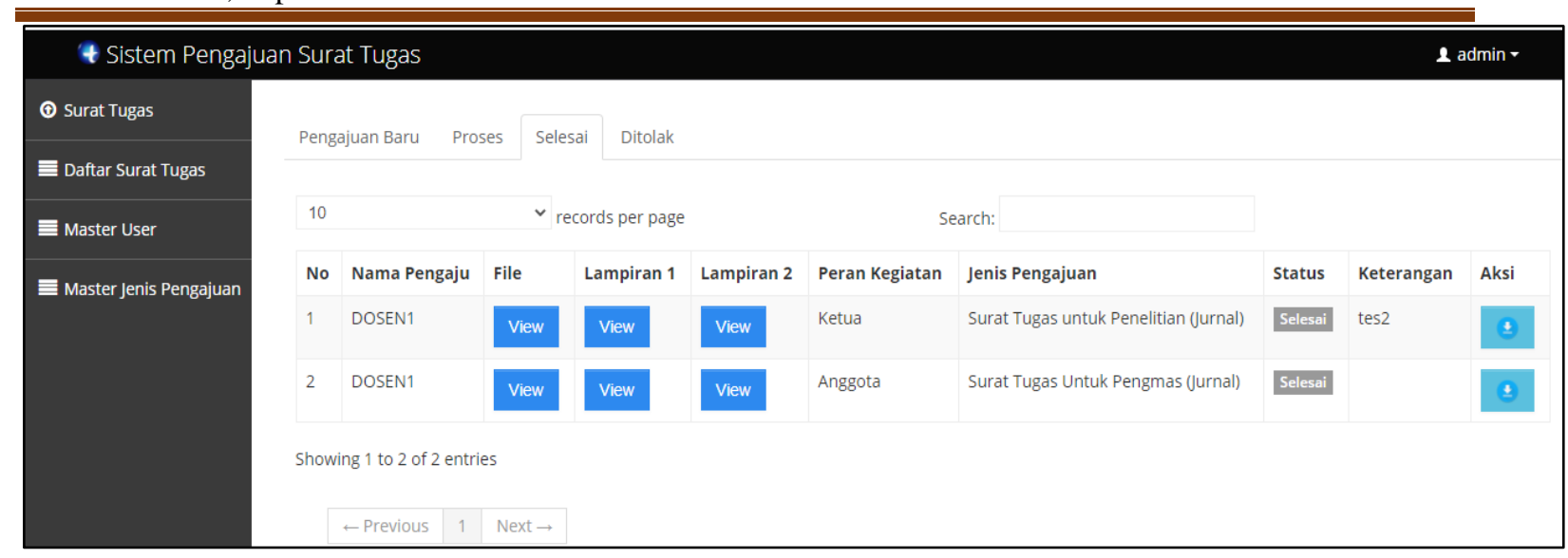

Gambar 13. Menu Proses Ajuan Surat Selesai

Gambar dibawah ini adalah menu utama untuk dosen. Gambar 14 merupakan tampilan utama laman dosen yang terdiri dari sub menu pengajuan baru, proses, selesai dan ditolak.

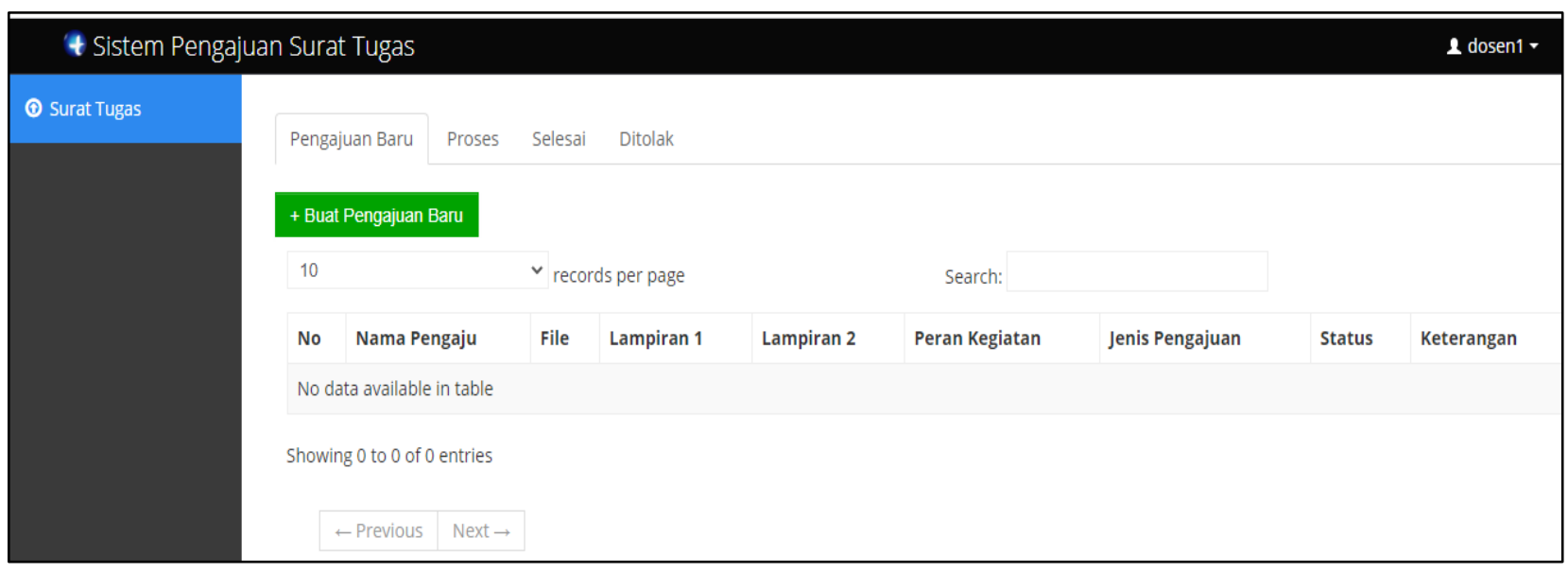

Gambar 14. Menu Utama Dosen

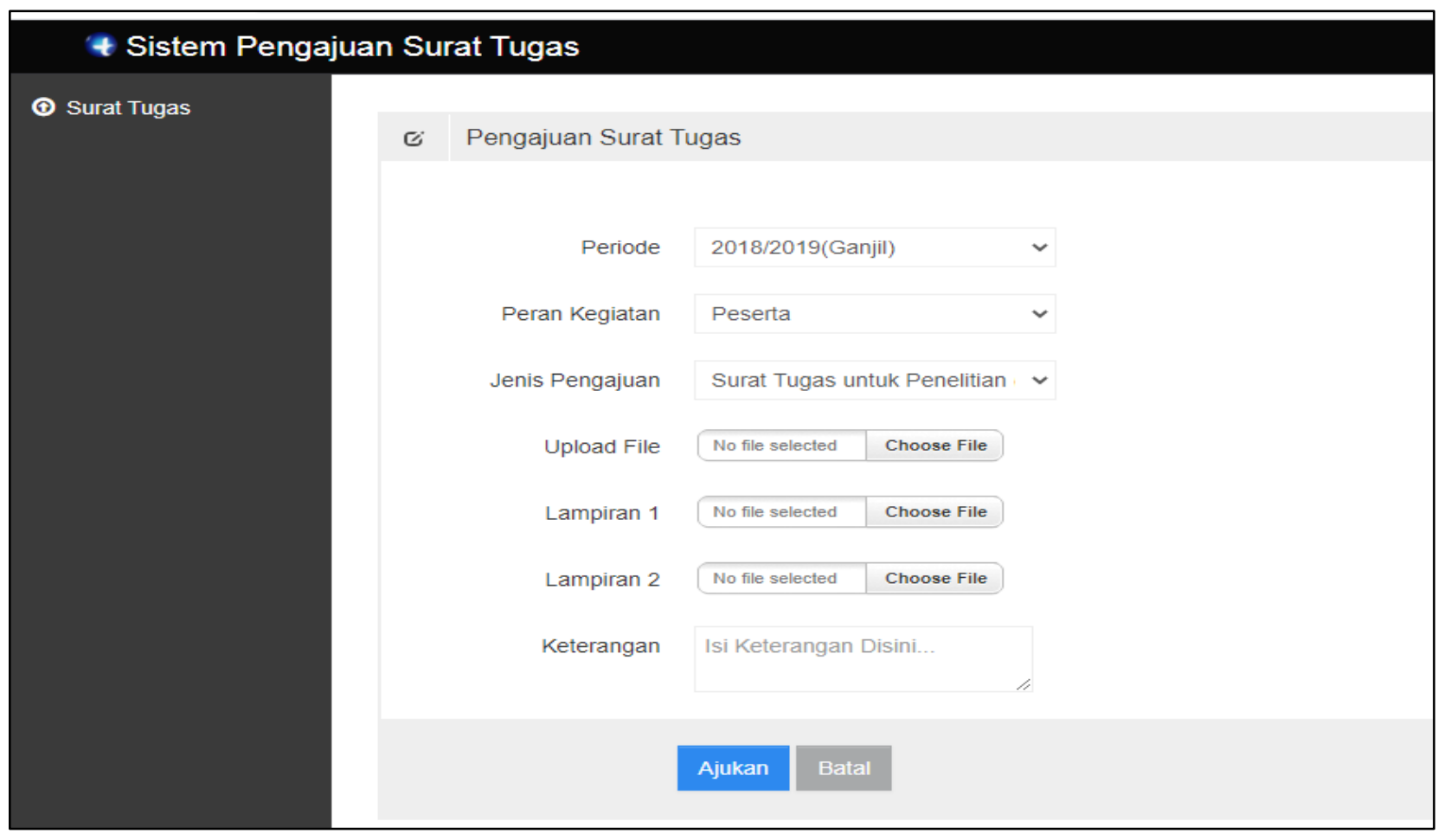

Gambar 15. Menu Pengajuan Surat oleh Dosen 
Pada gambar 15 merupakan halaman untuk pengajuan surat oleh dosen. Terdiri dari input periode, peran kegiatan, jenis pengajuan, upload file dan lampiran serta ketergan. Untuk mengajukan surat, dosen dapat memilih / klik tombol ajukan.

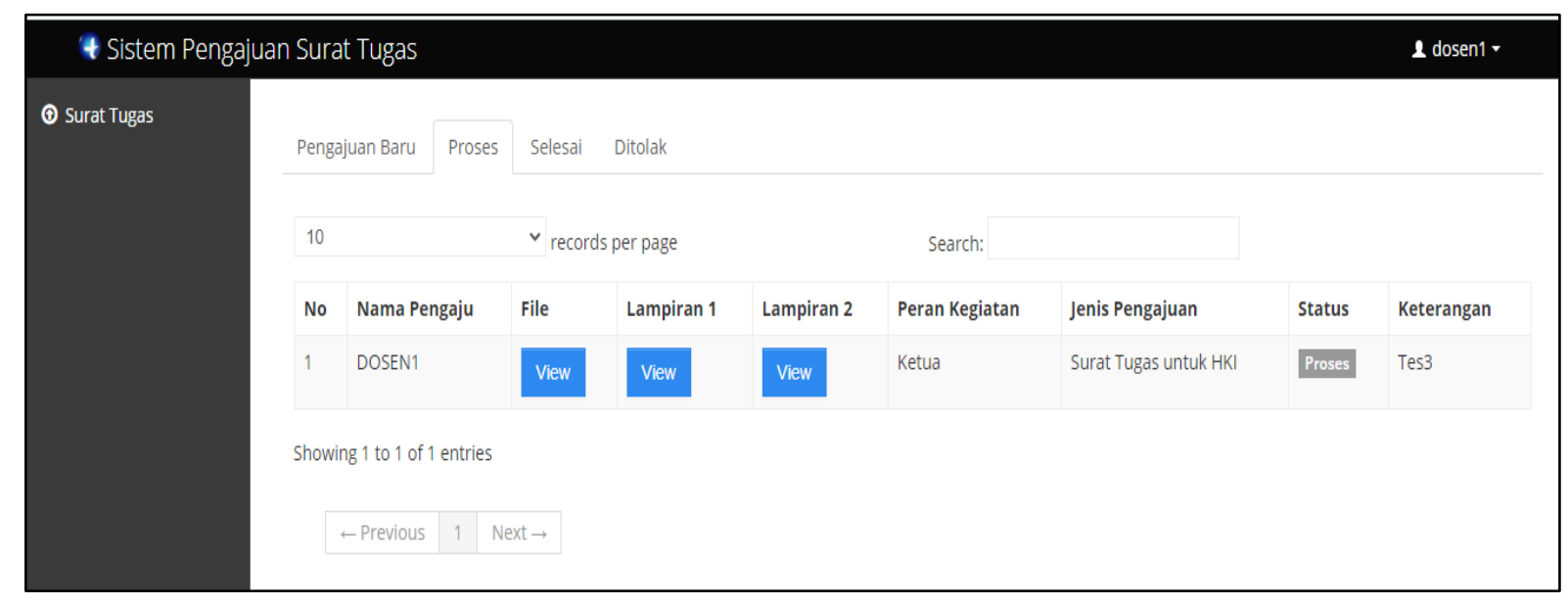

Gambar 16. Menu Proses Pengajuan Surat

Pada gambar 16 merupakan halaman sub menu proses. Yaitu halaman yang menjelaskan bahwa ajuan surat sedang diproses dan ditindak lanjuti oleh admin LPPM. Apabila proses telah selesai oleh admin LPPM maka dapat dilihat pada sub menu selesai pada gambar 17. Dosen dapat mengunduh surat yang telah selesai yang diberikan oleh LPPM dengan memilih tombol aksi download dengan simbol panah. Apabila pengajuan surat dosen ditolak oleh admin LPPM dapat dilihat pada sub menu ditolak dan dapat juga dilihat alasan ditolaknya. Pengajuan surat ditolak dapat dilihat pada gambar 18. Apabila pengajuan surat ditolak, maka dosen dapat mengajukan kembali dengan melihat alasan-alasan atau keterangan pada sub menu ditolak tersebut.

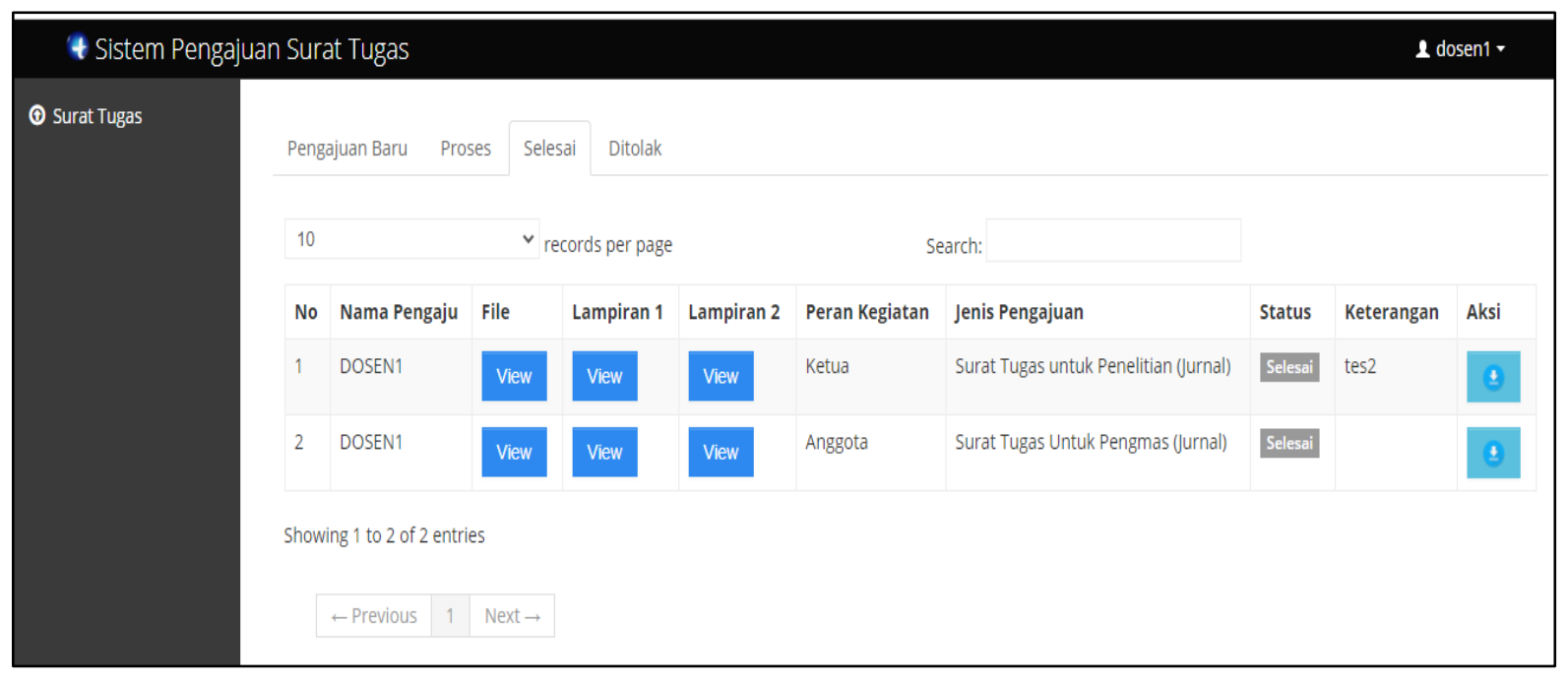

Gambar 17. Menu Proses Pengajuan Surat Selesai 


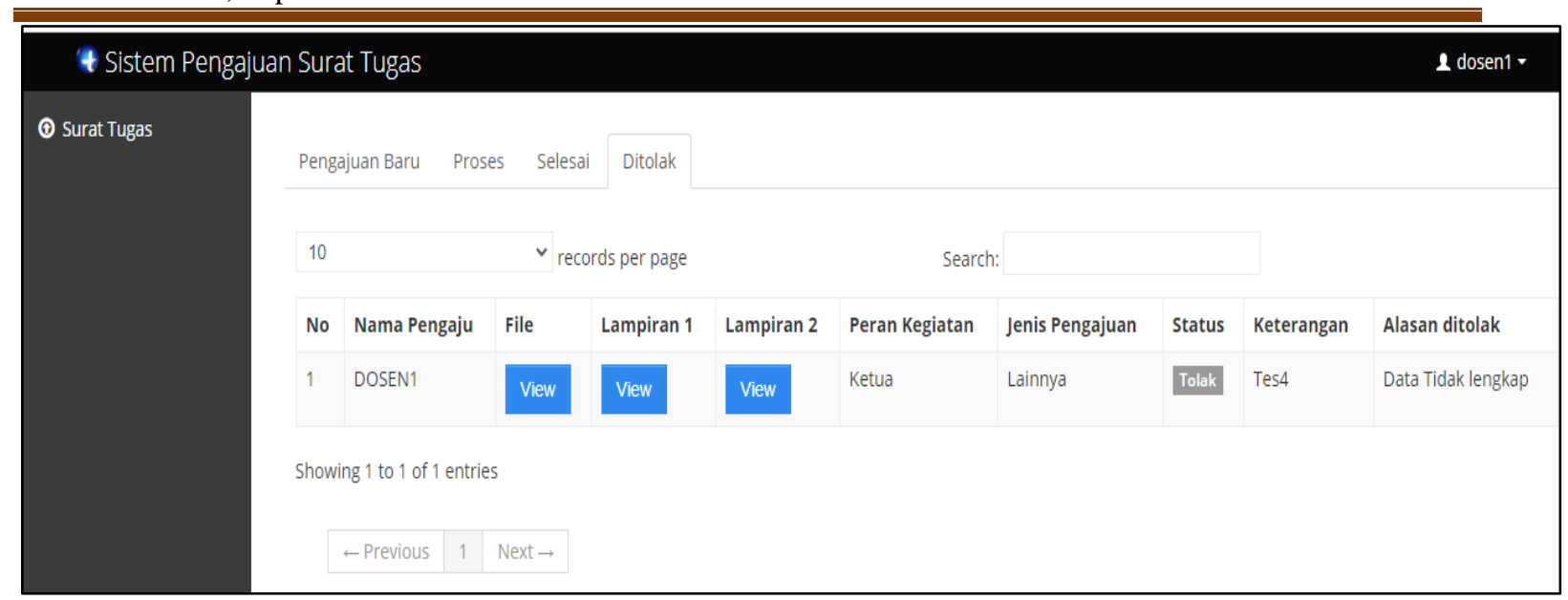

Gambar 18. Menu Proses Pengajuan Surat di Tolak

Pada tahapan akhir dilakukan pengujian aplikasi. Pengujian dilakukan dengan pendekatan Black Box Testing, Yaitu menguji aplikasi dari segi spesifikasi fungsional tanpa menguji desain dan kode program. Pengujian yang dilakukan oleh pengembang perangkat lunak untuk mendapatkan set kondisi masukkan yang sepenuhnya akan melaksanakan semua persyaratan fungsional suatu program.

Pengujian dengan Black Box Testing yaitu pengujian fungsional tanpa melihat alur eksekusi program, namun cukup dengan memperhatikan apakah setiap fungsi sudah berjalan dengan baik, fungsi-fungsi yang diuji adalah proses login, tombol-tombol menu, dan tombol-tombol sub menu.

Dari hasil pengujian dengan menggunakan Black Box Testing dapat disimpulkan bahwa aplikasi surat yang dikembangkan dapat berfungsi sesuai dengan yang diharapkan serta aplikasi yang dikembangkan telah cukup memenuhi tujuan awal dari penelitian ini.

\section{KESIMPULAN DAN REKOMENDASI}

Berdasarkan dari analisis rancangan aplikasi diatas dapat disimpulkan sebagai berikut:

1. Model View Controller dapat diterapkan pada framework codeigniter dan dengan arsitektur $M V C$ mempermudah dalam perbaikan dan perubahan source code tanpa merubah keseluruhan logic pemrograman.

2. Dari hasil pengujian menggunakan pengujian Black Box Testing bahwa aplikasi surat dapat berfungsi dengan baik dan memenuhi tujuan awal pengembangan aplikasi ini.

\section{REFERENSI}

A. Sofwan, (2016) Belajar PHP dengan Framework CodeIgniter [online]. Available : http://ilmukomputer.org/2010/05/02/belajar-php-dengan-framework-code-igniter. [Accessed: 07-Dec-2017]. 
Fowler, M. (2005). Panduan Singkat Bahasa Pemodelan Objek Standar. Yogyakarta: Andi.

Nugroho, A. (2015). Analisis dan Perancangan Sistem Informasi. Bandung: Informatika Bandung.

Rahmah, D. L. (2014). Perancangan Aplikasi Sistem Persuratan Berbasis Web Pada PT. Dwi Pilar Pratama. Faktor Exacta, III(7), 282-292.

Sidik., Betha. Framework Codeigniter. Infomatika Bandung, 2012.

Sugiharti, E., \& Triliani, S. E. (2014). Perancangan Aplikasi Surat Masuk dan Keluar pada PT. Angkasa Pura 1 Semarang. Scientific Journal of Informatics, I(1), 39-52.

Supriadi, I., Indrayani, R., \& Maulydda, V. T. (2018). Rancang Bangun Aplikasi Surat Masuk Dan Surat Keluar Berbasis Web Pada Kantor Asuransi Jiwa Kantor Layanan Administrasi Bandung. Konferensi Nasional Sistem Informasi 2018, 980985.

Wursanto. (1991). Pembimbing Administrasi dan Surat-menyurat. Yogyakarta: Andi.

Zakir, A. (2016). Rancang Bangun Responsive Web Layout dengan Menggunakan Bootstrap Framework. Jurnal Nasional Informatika dan Teknologi Jaringan. 